\title{
Physical and Chemical Status of Drinking Water from Water Treatment Plants on Greater Zab River
}

\author{
${ }^{1}$ KAFIA, M. SHAREEF; ${ }^{2}$ SLAIMAN, G. MUHAMAD; ${ }^{3}$ NAZANIN, M. SHEKHANI \\ ${ }^{\prime}$ College of Nursing, Hawler Medical University, Erbil, Kurdistan, Iraq. 096466 4558666.E-mail:sksvme@yahoo.com \\ ${ }^{2}$ College of Science, University of Salahaddin, Erbil, Kurdistan, Iraq. ${ }^{3}$ College of Education, University of Salahaddin, Erbil, Kurdistan, \\ Iraq
}

\begin{abstract}
The contamination of surface waters through human activities has been intensified over the past years as the population density has increased. In order to ascertain the drinking water quality of Greater Zab river in Erbil, Kurdistan, Iraq, for human consumptions, water samples were collected from three water treatment plants (WTP) on that river. The following water quality parameters were determined which were chosen as the major indicators namely PH, Total Dissolved Solid(TDS), Electrical conductivity(EC), Total Hardness(TH), $\mathrm{Cl}^{-} \mathrm{F}^{-}, \mathrm{Na}^{+}$, $\mathrm{K}^{+}, \mathrm{Ca}^{+2}, \mathrm{Mg}^{+2}, \mathrm{NO}^{-}, \mathrm{SO}_{4}^{-2}, \mathrm{PO}^{-3}$ and the concentration of eight heavy metals $(\mathrm{Fe}, \mathrm{Pb}, \mathrm{Hg}, \mathrm{Zn}, \mathrm{Cd}, \mathrm{Ni}, \mathrm{Cu}$, and Ag. Concentrations of the metals in the water samples were determined by flame atomic absorption spectrometry. The research Results showed that efficiency of filtration unit of the three WTPs was: Efraz 1> Efraz 2> Efraz 3. Most of the parameters analyzed in this study were within the guidelines given by WHO or US EPA for drinking water while few others were not. @ JASEM
\end{abstract}

Water quality is a growing global concern. Polluted water and inadequate sanitation kill two children every minute worldwide. Water quality is the physical, chemical and biological characteristics of water in relationship to a set of standards. The primary uses considered for such characterization are parameters which relate to drinking water, safety of human contact, and for health of ecosystem. Interest in water analysis is due to the enormous importance of water to all categories of living things. It is necessary for the healthy development of man, animals and plants (Naveen, 2007). According to the Australian drinking water guidelines: drinking water must not contain chemicals, inorganic substances or organisms that may be harmful to human health. Drinking water should also be at reasonable temperature and be free of unappealing odours, taste and colour .The guideline defines drinking water as water which is safe to drink over a life time that is, it constitutes no significant risk to health. Investigations of the quality of drinking water have been continuously performed by researchers (Maria et al, 2009; Jos, 2009) around the world with rapid urbanization; the chemical aspects of water quality have become a cause of increasing concern as toxic chemicals in industrial effluents pose a high risk to human health. Two surveys of consumer satisfaction with drinking water quality conducted in Tiwan (Chung, 2007), in both surveys, the main reasons that respondents did not drink tap water was "water sources are inappropariate" and "unpleasant mouth feel". A study conducted on the level of inorganic elements and heavy metals $(\mathrm{Na}, \mathrm{Mg}, \mathrm{Fe}, \mathrm{Ni}, \mathrm{Co}, \mathrm{Cu}$, $\mathrm{Cd}, \mathrm{Pb}$ and $\mathrm{Zn}$ ) in Kallar Kahar lake (Furhan, 2005), indicated that the concentration of the studied elements were not within the safe limit at the sampling sites throughout the studied period and the
Kallar Kahar lake is not suitable for drinking, farming and agriculture. This study was aimed to evaluate the quality of Greater Zab river water for drinking and irrigation purposes. Also to determine the physical, chemical and the dissolved concentration of trace metals in drinking water from the three (WTP) on Greater Zab at Efraz village and to qualify the efficiency of their filtration unit.

\section{MATERIALS AND METHODS}

\section{Reagents and Solutions}

Analytical reagent grade chemicals were employed for the preparation of all solutions. Freshly prepared deionized water was used in all experiments.

\section{Apparatus \\ Prior to analysis, all instruments were calibrated according to manufacturer's recommendations. $\mathrm{PH}$ was measured by using Portable $\mathrm{PH}$-meter (HANNA instrument model PHB) with combined electrode. EC was determined by conductivity meter Hi8314. Sodium and Potassium ions were measured by Flame photometer model Jenway PEP7 England (UK).Turbidity was measured by turbidity meter $\mathrm{Hf}$ Scientific, inc. model BRF 15CE. Fe, Pb, Hg, Zn, Cd, $\mathrm{Ni}, \mathrm{Cu}$, and $\mathrm{Ag}$ were determined by Flame Atomic Absorption Spectroscopy.}

\section{Experimental Sites}

Erbil is the capital of Iraqi Kurdistan and situated in the northeast of Iraq. The Greater-zab river(Bahdinan river) is the only source of surface water in Erbil city for drinking and other purposes(Shuokr, 2007). Three WTPs were constructed on this river at Efraz village. Water samples were gathered from three (WTPs), on five different locations were indicated as sampling site. 
1- River (input point).

2- Before sedimentation.

3- After filtration.

4- After chlorination.

5- Output.

\section{Sample collection}

The sampling was carried out at March 2008. Water samples were collected in pre-washed (with detergent water solution, rinsed with tap water and socked for 48 hours in $50 \%$ HNO3 then rinsed thoroughly with distilled de-ionized water) polyethylene bottles(Ramizankhani et al, 2008; Soylak et al, 2002). They were then air-dried in a dust free environment. At each sampling location, water samples were collected in two polyethylene bottles. Before tacking final water samples, the bottles were rinsed three times with water to be collected (Wajahat and Sajida,
2006). The sample bottles were labelled with date and sampling source. $\mathrm{PH}$ and electrical conductivity of the samples were measured while collecting the samples. Samples for sulphate and phosphate were refrigerated and analyzed within 24 hours (Alam, 2007).

Water samples were collected for analysis according to recommended procedures (Adekunle et al, 2007; Frank; Eaton, 1998; Parason, 1984; Bartram, 1996).

The following water quality parameters were determined which were chosen as the major indicators namely $\mathrm{PH}$, TDS, EC, TH, $\mathrm{F}^{-}, \mathrm{Cl}^{-}, \mathrm{Na}^{+}, \mathrm{K}^{+}$ $, \mathrm{Ca}^{+2}, \mathrm{Mg}^{+2}, \mathrm{NO}^{-}, \mathrm{SO}^{-2}, \mathrm{PO}^{-3}$ and the concentration of eight heavy metals ( $\mathrm{Fe}, \mathrm{Pb}, \mathrm{Hg}, \mathrm{Zn}$, $\mathrm{Cd}, \mathrm{Ni}, \mathrm{Cu}$, and $\mathrm{Ag}$ ). All assays were carried out at least three times and the means of all the values were calculated.

Table 1: Some physical and chemical properties of water samples from the selected sites.

\begin{tabular}{|c|c|c|c|c|c|c|c|c|c|}
\hline $\begin{array}{l}\text { Sample } \\
\text { Location }\end{array}$ & $\begin{array}{l}\text { Turb. } \\
\text { TUN }\end{array}$ & $\mathrm{PH}$ & $\begin{array}{l}\text { EC } \\
\mu \mathrm{scm}^{-}\end{array}$ & $\begin{array}{l}\text { TDS } \\
\mathrm{mgL}^{-1}\end{array}$ & ${ }_{1}^{\mathrm{T}} . \mathrm{H} \mathrm{mgL}^{-}$ & $\begin{array}{l}\mathrm{NO}^{-} \\
\mathrm{mgL}^{-1}\end{array}$ & $\begin{array}{l}\mathrm{SO}^{-2} \\
\mathrm{mgL}^{-1}\end{array}$ & $\begin{array}{l}\mathrm{PO}^{-3}{ }^{-3} \\
\mathrm{mgL}^{-1}\end{array}$ & $\begin{array}{l}\mathrm{NH}_{4}^{+} \\
\mathrm{mgL}^{-1}\end{array}$ \\
\hline \multicolumn{10}{|l|}{ Efraz 1} \\
\hline Site 1 & 11 & 8.2 & 200 & 215 & 228 & 9 & 187 & 0.07 & 0.15 \\
\hline Site 2 & 10 & 6.5 & 245 & 275 & 227 & 7 & 170 & 0.08 & 0.11 \\
\hline Site 3 & 6 & 7.5 & 203 & 211 & 230 & 4 & 156 & 0.08 & 0.10 \\
\hline Site 4 & 3 & 7.4 & 230 & 266 & 229 & 6 & 143 & 0.08 & 0.09 \\
\hline Site 5 & 3 & 7.1 & 235 & 283 & 231 & 6 & 150 & 0.08 & 0.11 \\
\hline \multicolumn{10}{|l|}{ Efraz 2} \\
\hline Site 1 & 11 & 7.9 & 195 & 210 & 234 & 4 & 160 & 0.10 & 0.13 \\
\hline Site 2 & 10 & 7.5 & 240 & 276 & 230 & 3 & 165 & 0.09 & 0.12 \\
\hline Site 3 & 2 & 7.5 & 200 & 215 & 220 & 3 & 155 & 0.08 & 0.10 \\
\hline Site 4 & 2 & 7.0 & 235 & 270 & 225 & 1.5 & 150 & 0.09 & 0.10 \\
\hline Site 5 & 1 & 7.5 & 237 & 272 & 231 & 2 & 145 & 0.07 & 0.09 \\
\hline \multicolumn{10}{|l|}{ Efraz 3} \\
\hline Site 1 & 12.5 & 8 & 205 & 228 & 230 & 4 & 150 & 0.08 & 0.12 \\
\hline Site 2 & 7 & 6.5 & 250 & 286 & 225 & 3 & 160 & 0.09 & 0.09 \\
\hline Site 3 & 1 & 7.4 & 205 & 220 & 222 & 3 & 145 & 0.08 & 0.09 \\
\hline Site 4 & 1.1 & 7.1 & 240 & 279 & 230 & 4 & 132 & 0.08 & 0.08 \\
\hline Site 5 & 0.8 & 7.4 & 240 & 279 & 228 & 3 & 140 & 0.08 & 0.08 \\
\hline
\end{tabular}

Table 2: Concentration of $\mathrm{F}^{-}, \mathrm{Cl}^{-}, \mathrm{Na}^{+}, \mathrm{K}^{+}, \mathrm{Ca}^{+2}, \mathrm{Mg}^{+2}$ of water samples from the selected sites.

\begin{tabular}{|c|c|c|c|c|c|c|}
\hline $\begin{array}{l}\text { Sample } \\
\text { Location }\end{array}$ & $\mathrm{mgL}^{-1} \mathrm{~F}^{-}$ & $\begin{array}{c}\mathrm{Cl}^{-} \\
\mathrm{mgL}^{-1}\end{array}$ & $\begin{array}{c}\mathrm{Na}^{+} \\
\mathrm{mgL}^{-1}\end{array}$ & $\begin{array}{c}\mathrm{K}^{+} \\
\mathrm{mgL}^{-1}\end{array}$ & $\begin{array}{c}\mathrm{Ca}^{+2} \\
\mathrm{mgL}^{-1}\end{array}$ & $\begin{array}{l}\mathrm{Mg}^{+2} \\
\mathrm{mgL}^{-1}\end{array}$ \\
\hline \multicolumn{7}{|l|}{ Efraz 1} \\
\hline Site 1 & 0.05 & 7 & 9 & 2 & 28 & 31 \\
\hline Site 2 & 0.05 & 8 & 10 & 2 & 28 & 32 \\
\hline Site 3 & 0.04 & 10 & 14 & 1.4 & 36 & 27 \\
\hline Site 4 & 0.04 & 13 & 10 & 1.6 & 32 & 26 \\
\hline Site 5 & 0.6 & 6 & 8.1 & 1.3 & 30 & 31 \\
\hline \multicolumn{7}{|l|}{ Efraz 2} \\
\hline Site 1 & 0.05 & 9 & 9 & 2 & 39 & 34 \\
\hline Site 2 & 0.05 & 9 & 7 & 2.4 & 31 & 34 \\
\hline Site 3 & 0.06 & 6 & 7 & 1.9 & 21 & 36 \\
\hline Site 4 & 0.05 & 12 & 8.4 & 2.1 & 28 & 38 \\
\hline Site 5 & 0.5 & 5 & 7.9 & 1.87 & 27 & 30 \\
\hline \multicolumn{7}{|l|}{ Efraz 3} \\
\hline Site 1 & 0.05 & 8 & 8.5 & 1.1 & 32 & 30 \\
\hline Site 2 & 0.08 & 8.5 & 8 & 1.2 & 29 & 29 \\
\hline Site 3 & 0.06 & 7 & 8.1 & 1.2 & 30 & 31 \\
\hline Site 4 & 0.05 & 11 & 8.2 & 1.3 & 30 & 30 \\
\hline Site 5 & 0.5 & 6 & 8.1 & 1.3 & 30 & 31 \\
\hline
\end{tabular}


Table 3: concentrations of $\mathrm{Fe}, \mathrm{Pb}, \mathrm{Hg}, \mathrm{Zn}, \mathrm{Cd}, \mathrm{Ni}, \mathrm{Cu}$ and $\mathrm{Ag}$ in water samples from the selected sites.

\begin{tabular}{lcccccccc}
\hline $\begin{array}{l}\text { Sample } \\
\text { Location }\end{array}$ & $\begin{array}{c}\mathrm{Fe} \\
\mathrm{mgL}^{-1}\end{array}$ & $\begin{array}{c}\mathrm{Pb} \\
\mathrm{mgL}^{-1}\end{array}$ & $\begin{array}{c}\mathrm{Hg} \\
\mathrm{mgL}^{-1}\end{array}$ & $\begin{array}{c}\mathrm{Zn} \\
\mathrm{mgL}^{-1}\end{array}$ & $\begin{array}{c}\mathrm{Cd} \\
\mathrm{mgL}^{-1}\end{array}$ & $\begin{array}{c}\mathrm{Ni} \\
\mathrm{mgL}^{-1}\end{array}$ & $\begin{array}{c}\mathrm{Cu} \\
\mathrm{mgL}^{-1}\end{array}$ & $\begin{array}{c}\mathrm{Ag} \\
\mathrm{mgL}^{-1}\end{array}$ \\
\hline $\begin{array}{l}\text { Efraz 1 } \\
\text { Site 1 }\end{array}$ & 0.221 & 0.00702 & 0.00812 & 29.43 & 0.0292 & 4.216 & 0.417 & 0.269 \\
Site 2 & 0.202 & 0.00684 & 0.0078 & 28.74 & 0.0281 & 4.119 & 0.402 & 0.281 \\
Site 3 & 0.228 & 0.00816 & 0.00791 & 27.63 & 0.0279 & 3.91 & 0.412 & 0.261 \\
Site 4 & 0.206 & 0.00592 & 0.00673 & 28.14 & 0.0251 & 4.012 & 0.393 & 0.255 \\
Site 5 & 0.182 & 0.00617 & 0.00612 & 29.83 & 0.269 & 3.823 & 0.381 & 0.217 \\
Efraz 2 & & & & & & & & \\
Site 1 & 0.283 & 0.00810 & 0.00670 & 30.7 & 0.023 & 5.821 & 0.271 & 0.187 \\
Site 2 & 0.266 & 0.0080 & 0.00650 & 32.1 & 0.0 .22 & 5.673 & 0.218 & 0.193 \\
Site 3 & 0.289 & 0.0073 & 0.00590 & 29.4 & 0.024 & 6.726 & 0.28 & 0.175 \\
Site 4 & 0.280 & 0.00828 & 0.00601 & 31.1 & 0.20 & 5.735 & 0.205 & 0.164 \\
Site 5 & 0.281 & 0.00805 & 0.00600 & 30.2 & 0.021 & 4.365 & 0.214 & 0.172 \\
Efraz 3 & & & & & & & & \\
Site 1 & 0.351 & 0.00737 & 0.00817 & 27.32 & 0.0203 & 3.294 & 0.19 & 0.204 \\
Site 2 & 0.295 & 0.00772 & 0.00741 & 25.65 & 0.0217 & 3.73 & 0.17 & 0.172 \\
Site 3 & 0.208 & 0.00544 & 0.00892 & 22.82 & 0.0181 & 2.83 & 0.16 & 0.116 \\
Site 4 & 0.251 & 0.00592 & 0.00801 & 16.091 & 0.0163 & 4.12 & 0.19 & 0.123 \\
\hline Site 5 & 0.280 & 0.00518 & 0.00812 & 18.11 & 0.016 & 3.163 & 0.16 & 0.127 \\
\hline
\end{tabular}

\section{RESULTS AND DISCUSSION}

The average of the main physical and chemical properties (PH, TDS, EC, TH , $\mathrm{NO}^{-}, \mathrm{SO}^{-2}, \mathrm{PO}^{-3}$ and $\mathrm{NH}^{+}$) of water samples from Greater-zab river and the three WTPs were given in Table 1.Turbidity of water samples after treatment at the three WTPs were (0.8-3) lower than the acceptable value recommended by WHO (2004). Values of PH of river water (6.5-8.4) and drinking water (7.1-7.5) samples were within WHO acceptable limit, making it marginal for irrigation and drinking purposes.

Values of EC of water samples from selected sites were (195-250 ms) lower than the acceptable level recommended by WHO (2004). The level of TDS was from 210 to $286 \mathrm{mgL}^{-1}$ and was all lower than the acceptable level $\left(500 \mathrm{mgL}^{-1}\right)$. TDS is a measure of all the chemical constituents dissolved in water, it is mostly influenced by the concentration of major ions ; calcium, bicarbonate, magnesium, sulfate and chloride and it is closely linked to the EC. Regarding TH all studied sites considered safe for drinking purposes, values of $\mathrm{TH}$ were from 200 to $234 \mathrm{mgL}^{-1}$, were lower than the acceptable level(500 $\left.\mathrm{mgL}^{-1}\right)$. Maximum contaminant level (MCL) of $\mathrm{NO}^{-}$ according to WHO (2004) is $10 \mathrm{mgL}^{-1}$. In drinking water samples after treatment $\mathrm{NO}^{-}$concentrations were 6,2 and $3 \mathrm{mgL}^{-1}$ respectively. Source of $\mathrm{NO}^{-}$in surface water is runoff from fertilized use, leaching from septic tanks, sewage and erosion of natural deposits. The concentrations of $\mathrm{SO}^{-2}$ after treatment (150, 145 and 140 respectively) were within the acceptable level. Sulphate is aboundant ion in the earth crust and is concentration in water ranged between few milligrams to thousand milligrams per liter. According to WHO (2004) guidelines for drinking water quality, $\mathrm{SO}^{-2}$ should be lower than $500 \mathrm{mgL}^{-1}$. PO4 ${ }^{-3}$ level in our samples were from 0.07 to $0.1 \mathrm{mgL}^{-1}$. Natural water rarely contain more than $0.1 \mathrm{mgL}^{-1} \mathrm{PO}^{-3}$ unless they have passed through soil containing phosphate or have polluted by organic matter. Concentrations of NH4 in the studied sites were between 0.08 and $0.15 \mathrm{mgL}^{-1}$. Ammonia is not of direct importance for health in the concentrations to be expected in drinking water. So a health guideline has not been derived (WHO, 2004) although concentrations above $2 \mathrm{mgL}^{-1}$ detrimental to some aquatic organisms and interferes with disinfection process (Gwenzi and Munondo, 2006).

Concentration of $\mathrm{F}^{-}, \mathrm{Cl}^{-}, \mathrm{Na}^{+}, \mathrm{K}^{+}, \mathrm{Ca}^{+2}, \mathrm{Mg}^{+2}$ in water samples from the selected sites which summarized in Table 2 were; 0.04-0.06, 5-11, 7-14, 1.1-2.4, 21-39, 26-36 $\mathrm{mgL}^{-1}$ respectively. The concentration of the ions mentioned above were all lower than MCL suggested by WHO (2004).

The water samples collected from fifteen sampling sites were analysed in triplicate to determine the concentrations of trace elements including $\mathrm{Fe}, \mathrm{Pb}$, $\mathrm{Hg}, \mathrm{Zn}, \mathrm{Cd}, \mathrm{Ni}, \mathrm{Cu}$ and $\mathrm{Ag}$ are given in Table 3. Since trace metal standards were developed from laboratory data in the mid - 198s, there has been a continuing challenge in making field observation at concentrations as low as the calculated criteria(Paul and Austin, 1998).Concentration of $\mathrm{Fe}, \mathrm{Pb}, \mathrm{Hg}, \mathrm{Cd}$, and $\mathrm{Cu}(0.182-0.351,0.00518-0.00828,0.00591-$ $0.0089, \quad 0.016-0.0292, \quad 0.16-0.417 \quad \mathrm{mgL}^{-1}$ respectively) were within the limit permitted by USEPA(2006). While the concentration of $\mathrm{Zn}, \mathrm{Ni}$ and $\mathrm{Ag}$ (16.091-32.1, 2.83-6.726 and 0.116-0.281 $\mathrm{mgL}^{-1}$ respectively) were higher than the limit permitted by USEPA. The behaviour of heavy metals in natural water is a function of the substrate sediment composition, suspended sediments composition and the water chemistry. The high concentration of $\mathrm{Zn}$ may be due to discharge from small industries, sewages, various domestic and household sources. $\mathrm{Zn}$ is a secondary standard that may cause cosmetic 
effects or aesthetic effects in drinking water. EPA recommends secondary standards to water system but does not required systems to comply. Nickel occurrs naturally in some natural water and where necessary special treatment can be installed to remove it. Average silver concentrations in natural waters are $0.2-0.3 \mu \mathrm{gL}^{-1}$. Silver levels in drinking water in the USA that had not been treated with silver for disinfection purposes varied between "nondetectable" and $5 \mu \mathrm{gL}^{-1}$.

Comparing the level of turbidity before and after treatment $(11 \& 3,11 \& 1$ and $12.5 \& 0.8$ NTU respectively) at each WTP, we found that the efficiency of filtration unit at the three WTP were in the order; Efraz $3>$ Efraz $2>$ Efraz 1. It means that filtration unit in Efraz 1 is inefficient and turbidity is higher than MCL (1NTU). It means that Efraz 1 is an old project (constructed at 1969), it needs repairing and reconstruction. Although Turbidity has no health effect but it can interfere with disinfection and provide a medium for microbial growth it may indicate the presence of microbes.

The results from data analysis show that river water samples (from site 1) on Greater zab river are certainly unsafe for drinking purposes without any form of treatment, but safe for various other surface water usage purposes.

\section{REFERENCES}

Adekunle, L Adetunji M Gbadebo A (2007). Assesment of ground water quality in a typical rural settlement in south Nigeria, Int. J Environ. Res. Public Health 4(4): 307-318.

Alam B. Islam R. Muyen Z. Mamun M. Islam $\mathrm{S}(2007)$. Water quality parameters along rivers. Int. J. Environ. Sci. Tech. 4 (1): 159- 167.

Australian Drinking Water Guidelines, Drinking water facts. 4Bartram J and Balance R (1996). Water quality monitoring UNEP and WHOE FN spon, London, UK.

Chung L Lee L Han Y (2007). Influence of alkalinity, hardness and dissolved solids on drinking water test: A case study of consumer satisfaction, Journal of environmental Management 82: 1-12.

Eaton J (1998). "The elements" $3^{\text {rd }}$ Ed Clavendon press, Oxford, London.

Frank M D Environmental Laboratory Exercises for Instrumental Analysis and Environmental Chemistry Wiley Interscience, A John Wiley\& Sons, INC. Publication.
Furhan I Nadeem R Muhammad A Muhammad A (2005). Contamination of Kallarkahar Lake by inorganic elements and heavy metals and their temporal variations, Journal of Applied Sciences and Environmental Management 10 (2): 95-98.

Gwenzi W. Munondo R (2008). Long term effect of pasture irrigation with treated sewage effluent on shallow ground water quality, Water Science and Technology-WST 58 (12): 2443-2452.

Jos P (2009). The origin of speciation: Trace metal kinetics over natural water/sediment interface and the consequences for bioaccumulation, Environmental Pollution 157: 519-527.

Maria R. Agostino S. Marcella R(2009). Giovanni C. Cadmium adsorption on Vermiculite, Zeolite and Pumice, Journal of Environmental Management 90: 364-374.

Naveen K. Singh (2007). Chemical analysis of ground water collected from different areas of Antiri and some nearby Villages, Current World Environment 2 (1): 73-75.

Parason T Maita Y and Lalli C (1984). A manual of chemical and biological method for water analysis, Pergamon press, Oxford.

Paul J Austin J (1979). Clean Trace metal measurements in the Houston ship channel Msc. Thesis Texas A\&M University:35-40

Ramizankhani R. Shareef M Sadatipour M Abdulahzadeh R (2008). A mathematical model to predict Nickel concentration in Karaj River sediments Iran. J Environ. Sci. Eng 5 (2): 91-94.

Shuokr O (2007) Liminological observations on the water treatment plants in Efraz, $2^{\text {nd }}$ Environmental Conference- Water, Duhok, Kurdistan, Iraq. April.

Soylak M. Armagan F. Saracoglu S. Elci L. Dogan M (2002). Chemical Analysis of Drinking water Samples from Yozgat, Turkey Polish Journal of Environmental Studies 11 (2): 151-156.

Wajahat N Sajida P Syed Asif S (2006). Evaluation of irrigation water for heavy metals Akbarpura area Journal of Agricultural and biological Science 1 (1): 51-54.

WHO (2004). Guideline for drinking water quality $3^{\text {rd }}$ edition Vol.1 recommendations.WHO, Geneva 189 pp.

Drinking Water Contaminants (2006) Safe Water, US EPA, last updated on Tuesday November $28^{\text {th }}$. 